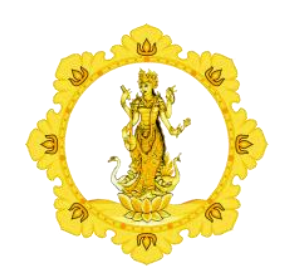

KALANGWAN

JURNAL PENDIDIKAN AGAMA, BAHASA DAN SASTRA

Vol. 9 No. 2 September 2019

\begin{tabular}{|l|l|l|}
\hline p-ISSN : 1979-634X & e-ISSN : 2686-0252 & http://ejournal.ihdn.ac.id/index.php/Kalangwan
\end{tabular}

\title{
ESENSI ETIKA DAN MORALITAS DALAM KITAB NITI SATAKA
}

\author{
Oleh : \\ Putu Sabda Jayendra, Gusti Ngurah Yoga Semadi \\ Sekolah Tinggi Pariwisata Bali Internasional \\ E-mail: sabda@stpbi.ac.id, yogasemadi@stpbi.ac.id
}

Diterima 05 Juli 2019, direvisi 02 Agustus 2019, diterbitkan 2 September 2019

\begin{abstract}
Kitab Niti Sataka berisi tentang 100 buah sloka yang ditulis oleh Raja Bhartrihari sekitar dua ribu silam. Beliau adalah raja yang sangat pandai memimpin dan disayangi rakyatnya, disamping itu beliau juga ahli dalam filsafat dan bahasa Sansekerta. Kitab Niti Sataka mengandung ajaran tentang nilai-nilai etika dan moralitas yang sangat bermanfaat di dalam kehidupan, terlebih di zaman modern ini. Namun esensi etika dan moralitas dalam kitab Niti Sataka belum dikenal secara umum oleh umat Hindu. Ajaran yang terkandung di dalamnya sesungguhnya merupakan ajaran-ajaran susila (etika dan moralitas) dengan ungkapan-ungkapan bahasa kekinian yang mudah dicerna oleh masyarakat umum, serta dapat diaplikasikan dalam upaya pembentukan karakter sejak dini.
\end{abstract}

Keywords: Niti Sataka, Nilai-nilai Pendidikan

\section{PENDAHULUAN}

Ajaran agama Hindu banyak mengandung mutiara-mutiara yang indah untuk memberikan kebahagiaan hidup bila ditelusuri dan dilaksanakan. Dalam kehidupan sehari-hari, usaha untuk mendekatkan diri kepada Ida Sang Hyang Widhi Wasa atau Tuhan Yang Maha Kuasa hendaknya senantiasa ditingkatkan. Bila manusia menyadari bahwa hidup ini penuh dengan arti, manfaatkan dan isilah hidup ini dengan kasih yang bisa dipancarkan kepada setiap orang. Doa, budaya (etos) kerja dan kepemimpinan Hindu hendaknya diresapi oleh setiap individu. Di samping itu, ajaran agama lebih diproyeksikan ke dalam diri pribadi untuk kebaikan setiap orang, keluarga, dan masyarakat (Titib, 1994: 96-97).

Salah satu tuntunan untuk mencapai hal tersebut dapat ditemukan dalam ajaran kitab 
Niti Sataka. Kitab Niti Sataka merupakan salah satu susastra suci Hindu yang sarat akan nilai-nilai etika, moralitas dan spiritual. Kitab Niti Sataka berisi tentang 100 buah sloka yang ditulis oleh Raja Bhartrihari sekitar dua ribu silam. Beliau adalah raja yang sangat pandai memimpin dan disayangi rakyatnya, disamping itu beliau juga ahli dalam filsafat dan bahasa Sansekerta. Kitab Niti Sataka merupakan ajaran-ajaran etika dan moralitas yang mengandung mutiara-mutiara yang indah, disajikan dengan gaya bahasa yang khas yaitu 100 sloka ajaran etika dan moralitas, kemudian ditambahkan penjelasan dan ulasan dari Dr. Somvir yang menerjemahkan kitab ini.

Esensi etika dan moralitas yang terkandung dalam kitab Niti Sataka ini sangat perlu dan cocok diaplikasikan ditengah degradasi moral yang banyak melanda generasi milenial masa kini. Para ilmuwan pendidikan kebanyakan tidak mempelajari banyak dimensi kehidupan seperti apa yang telah para rși lakukan. Mereka masih mempelajari tentang otak dan berbagai macam daerahnya. Aspek psikologi yang mengacu kepada psikologi spiritual masih berada di luar jangkauan ilmuwan modern. Psikologi keabadian orang jaman dahulu adalah ilmu yang sebenarnya. Hal ini berdasarkan pada pengetahuan yang paling baik yang disebut dengan intuisi. Ilmu jasmaniah terbatas, dan pengamatan mereka hanya kepada sesuatu yang nyata, tubuh dan otak (Rama, 2005: 283). Merujuk kepada pendapat swami Rama tersebut di atas, maka manusia yang hidup di era sekarang ini perlu mengkaji pengetahuan dari dimensi psikologi spiritual, dengan menyeimbangkan antara pengetahuan jasmani (Para Vidya) dengan pengetahuan rohani (Brahma Vidya), sehingga keseimbangan hidup harmonis dapat tercapai, salah satunya adalah dengan upaya menerapkan ajaran-ajaran moralitas dalam masyarakat.

Sloka-sloka yang terdapat dalam Niti Sataka mengandung unsur-unsur nilai etika, moralitas, dan spiritual yang sangat baik bagi seluruh umat manusia tanpa mengenal batasan usia dan agama. Penyair Bharatihari menjalani tiga proses dalam kehidupan yakni pada saat beliau hidup sebagai manusia dalam masyarakat yang penuh dengan keduniawian, kemudian saat ia berusaha untuk melepaskan segala bentuk keterikatan duniawi, dan pada saat ia mencari kebebasan yang hakiki.

Dalam era globalisasi dan modernisasi saat sekarang ini, nilai-nilai etika dan moralitas terindikasi sudah semakin meluntur. Hal ini dapat dilihat dari berbagai macam fenomena perilaku manusia yang cenderung ke arah kekerasan atau anarkis. Sudah terjadi krisis nilai-nilai kemanusiaan yang seharusnya mengejawantah dalam diri, seperti nilai kebenaran, kebajikan, kedamaian, cinta kasih dan yang lainnya. Nilai-nilai yang terkandung dalam kitab Niti Sataka menjadi sebuah jawaban untuk kembali menghidupkan moralitas dalam masyarakat, serta sangat baik untuk anak-anak pelajar yang ingin memperdalam etika dan moralitas serta dapat menerapkannya dalam sendi-sendi kehidupan sehari-hari.

\section{PEMBAHASAN}

Beberapa aspek-aspek etika dan moralitas dalam membentuk karakter manusia secara seutuhnya dalam kitab Niti Sataka dapat dijabarkan sebagai berikut.

\subsection{Pendidikan Karakter}

Pengetahuan (Jnana) dalam ajaran Hindu adalah yang paling tinggi dan utama tingkatannya, pengetahuan ini sebagai biduk untuk menyeberangi lautan samudera luas yang bernama samsara (kelahiran berulangulang). Hal ini juga disebutkan dalam kitab Bhagawadgita (IV.33) sebagai berikut.

\section{Śreyān drayamayād yajūāj \\ jñānayajnāh paramtapa \\ sarvam karmā 'khilam pārtha \\ jūāne parisamāpyate.}

\section{Artinya:}

Wahai Arjuna sang penakluk musuh, melakukan persembahan suci melalui ilmu pengetahuan suci adalah lebih baik daripada persembahan-persembahan suci melalui harta benda. Wahai Arjuna, 
putra Dewi Partha (ketahuilah bahwa) seluruh perbuatan-perbuatan suci itu berakhir pada ilmu pengetahuan (Darmayasa, 2014: 326)

Berbicara tentang pendidikan adalah kaitannya dengan pembentukan watak seseorang menjadi seorang bijaksana atau waskita dalam bahasa jawa. Waskita berarti intelektual. Hal itu berarti bahwa waskita berkaitan dengan sektor pendidikan. Pendidikan merupakan hal yang sangat penting sebab dengan pendidikan orangorang akan dapat membenahi hal-hal yang kurang beres. Kekurangan dan ketertinggalan pada masa lampau, semestinya diperbaiki pada waktu kini, yakni yakni membenahi kekurangan-kekurangan itu. Jadi, waskita atau pendidikan merupakan kebutuhan utama di samping kebutuhan kehidupan yang lain. Dalam hal pendidikan agama Hindu ada dua macam, yakni (1) pendidikan jasmaniah atau pendidikan duniawi dan (2) pendidikan moral atau rohaniah (Gautama, 2005: 4). Dalam hal ini pendidikan yang perlu dikembangkan adalah berkenaan dengan nilai-nilai (karakter) dengan memadukan pendidikan nilai (integritas) antara pendidikan rohani dengan pendidikan jasmani, maka akan terjadi keselarasan akhlak atau martabat manusia sehingga dapat membentuk karakter.

Pembentukan karakter harus dimulai dari keteladanan. Keteladanan merupakan bentuk pendidikan berantai yang hidup. Ia tidak hanya memberikan informasi, tetapi juga mentransformasi sisi-sisi keagungan jiwa ke dalam hati generasi berikutnya. Keteladanan ibarat generasi yang diwariskan dari pendahulunya. Bila generasi pendahulunya unggul, dipastikan kelanjutan generasi berikutnya juga akan unggul, demikian sebaliknya. Keteladanan akan menghangatkan hati setiap generasi sehingga mampu menyalakan api jiwa untuk menuntun tapak-tapak hidupnya demi sebuah cita-cita kehidupan yang suci, penuh dedikasi, dan pengabdian (Suwantana, 2013: 2). Keteladanan dengan memberikan contoh yang baik (to be good example), sehingga menjadi panutan (role model) bagi peserta didik. Orang tua memegang peranan yang sangat penting dalam memberikan keteladanan, sebab guru pertama manusia yang lahir ke dunia ini adalah orang tua mereka, terutama ibu yang melahirkan.

Pendidikan karakter tersebut bahkan sudah dimulai semenjak anak yang bersangkutan masih ada dalam kandungan. Sebagaimana dikatakan Casper dalam Jumsai (2008:5-6) bahwa apa yang telah dilihat, didengar, atau diterima melalui organ-organ indra, apa pun yang telah dirasakan secara emosional, alam pikiran yang dilakukan melalui berbagai tindakan, dan apapun yang merupakan lingkungan pada masa lalu, semuanya tersimpan dalam bawah sadar. Hasil penelitian Casperdi dari Institute of Child Health and Human Development, University of Carolina telah menunjukkan bahwa bahkan selama masa kehamilan, emosi si ibu, jenis musik yang didengarkan, filmfilm yang sering ditonton dan jenis makanan yang dimakan selama masa kehamilan, semuanya tersimpan dalam pikiran bawah sadar bayi yang sedang dikandungnya dan kemudian akan memengaruhi kehidupan anak itu setelah lahir.

Manusia sejak lahir dalam tradisi Hindu sudah berbekal karma wesana (bekas-bekas perbuatan) yang masih dibawanya dalam kehidupan ini, karena belum habis dinikmati pada masa kehidupan sebelumnya. Biarpun manusia menguasai berbagai desiplin ilmu, ahli dalam segala hal maupun menguasai kekuatan yang lain, akan tetapi di dunia ini tidak ada yang bisa melawan kekuatan takdir atau hukum sebab akibat (karmaphala), seperti yang diuraikan dalam kitab Niti Sataka 98, yaitu:

Majjatvambhasi yātu meruśikharam satruñjayatvāhave vānijyam krṣisevanam ca sakalā vidyāh kalāh śikṣatu

$\bar{a} k \bar{s}$ sam vipulam prayātu khagavatkṛtvā prayatnam param

nābhāvyam bhavatiha karmavaśato bhāvyasya nāśah kutah.

Artinya : 
Meskipun seseorang menyelam ke samudera untuk mencari mutiara, mendaki gunung Semeru untuk mencari emas, mengalahkan musuh dalam peperangan, belajar dan berhasil dalam bisnis, pertanian, atau terbang ke angkasa bagaikan burung, di dunia ini semua terikat dengan karma, yang tidak terjadi tidak akan pernah terjadi dan mampu menghentikannya (Somvir, 2005: 84).

Biarpun manusia menguasai berbagai macam pengetahuan, maksudnya adalah pengetahuan yang perlu dicari adalah pengetahuan yang benar, yang bisa mengangkat harkat dan martabat manusia menuju kesempurnaan hidup. Adapun pengetahuan yang sangat dihormati bahkan dianggap bagaikan dewa yang dapat memenuhi berbagai keinginan. Hal ini tersirat dalam kitab Niti Sataka, 16 yaitu:

Vidyā nāma narasya rūpamadhikam pracchannaguptam dhanam

Vidyā bhogakarī yaśah sukhakarī vidyā gurunām guru

Vidyā bandhujano videśagamane vidyā parā devatā

Vidyā rājasu püjyate na hi dhanam vidyāvihinah pasuh.

\section{Artinya:}

Pengetahuan adalah kecantikan manusia yang paling agung dan merupakan harta yang tersembunyi. Ia adalah sumber dari semua kesenangan, kemasyuran, dan kebahagiaan. Ia adalah guru dari semua guru dan menjadi sahabat di negeri asing. Pengetahuan bagaikan dewa yang dapat mengabulkan setiap keinginan. Pengetahuanlah yang dihormati dalam pemerintahan, bukan kekayaan. Oleh karena itu, manusia tanpa pengetahuan yang benar bagaikan binatang (Somvir, 2005: 14).

Dalam ajaran agama Hindu pengetahuan dilambangkan dengan sosok dewi yang berparas cantik, yakni dewi Saraswati yang berarti selalu mengalir. Pengetahuan yang benar dilambangkan sebagai kecantikan, harta yang tersembunyi dan tidak dapat dinilai harganya, juga merupakan sumber kekayaan, kebahagiaan, dan sebagai sahabat dimanapun berada. Namun tanpa memiliki pengetahuan yang benar manusia dapat disamakan dengan keberadaan binatang, demikian kata penyair.

Selanjutnya karakter yang utama manusia bila manusia memiliki sifat penyabar, ia tidak memerlukan senjata apapun untuk dirinya, sebagaimana dijelaskan dalam Niti Sataka, 17 mengenai sifat-sifat manusia, yakni:

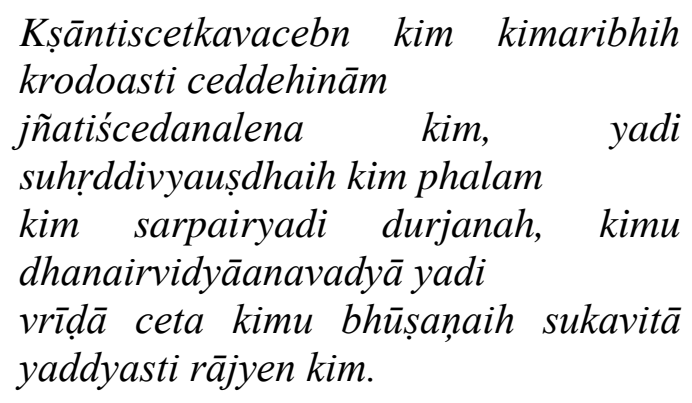

Artinya:

Bilamana seseorang memiliki sifat penyabar, ia tidak memerlukan senjata. Bilamana seseorang memiliki sifat pemarah, tidak perlu lagi mencari musuh. Bilamana ada kebanggaan terhadap kasta, tidak perlu lagi api yang lain, karena kebanggaan diri telah cukup membakar hatinya. Jika seseorang memiliki sahabat yang baik, maka tidak perlu mencari obat-obatan supranatural. Jika seseorang dikelilingi oleh orang-orang jahat, ia tidak perlu mencari ular yang berbisa. Jika ada pengatahuan yang baik dan benar, apa gunanya kekayaan lain? Jika seseorang adalah penyair yang baik, ia tidak perlu mengharapkan sebuah kerajaan (Somvir, 2005: 15).

Pengetahuan adalah kecantikan manusia yang paling agung dan merupakan harta yang tersembunyi, juga merupakan obat. Ia adalah sumber dari semua kesenangan, kemasyuran, dan kebahagiaan. Pengetahuanlah yang 
dihormati dalam pemerintahan, bukan kekayaan. Oleh karena itu, jika seseorang telah memiliki pengetahuan yang baik dan benar (karakter) maka ia tidak memerlukan kerajaan, karena kerajaan sesungguhnya sudah ada dalam diri sendiri.

Dengan menanamkan pendidikan karakter kearah kemurnian untuk tujuan yang sangat mulia sebagaimana yang diungkapkan Jumsai, yaitu anak-anak harus memiliki karakter yang baik dan hidup mereka harus diisi dengan nilai-nilai kemanusiaan. Pengembangan pikiran super sadar akan membantu munculnya kebijaksanaan, pemahaman, dan kemampuan untuk menghasilkan penemuan-penemuan baru. Kesadaran jati diri berarti bahwa anak-anak akan memahami siapa diri mereka, mengapa mereka ada di muka bumi ini, dan apa arti hidup mereka. Dengan demikian, hidup mereka menjadi lebih bermakna dan berguna (meaningful) bagi masyarakat dan bagi dunia (Jumsai, 2008: 11). Penanaman budi pekerti sejak usia dini akan mengarahkan manusia menuju kemurnian. Anak-anak akan lebih mengenal jati dirinya, lebih memahami hidup dengan penuh kesadaran, mendapatkan makna bagi dirinya, masyarakat lebih-lebih bagi dunia.

\subsection{Kreativitas}

Agar setiap orang bisa menjadi "the best" (yang terbaik) dari dirinya, Tuhan telah memberikan potensi (sumber kehebatan). Potensi itu ada yang terdapat di dalam diri seseorang, misalnya berupa berbagai kapasitas yang memungkinkan manusia untuk melakukan sesuatu. Bentuknya bisa potensi fisik, emosional, spiritual, atau intelektual (Latuconsina, 2014:22). Sebuah ide adalah dasar dari segala kreativitas. Kenyataan tentang hidup penuh dengan ketidakberuntungan bagi orang yang dapat menggunakan ide-ide dapat membuat orang tersebut menjadi sangat kreatif. Waktu adalah penyaring yang paling baik dan ide adalah kekayaan. Keberuntungan di tengah ketidakberuntungan dapat membantu manusia mengekspresikan ide dan kemampuannya pada waktu yang tepat (Rama, 2002: 216).
Segalanya ditentukan oleh waktu. Disinilah diperlukan kemampuan penuh konsentrasi dalam setiap usaha manusia, sehingga mampu memunculkan kreativitas yang tinggi serta upaya untuk memilah-milah dan mengingat akan kemampuan tersebut.

Kemampuan untuk berkonsentrasi meningkat dan daya ingat menjadi lebih baik. Peningkatan dalam konsentrasi dan ketenangan pikiran ini menyebabkan peningkatan dalam poses belajar. Melatih anak-anak seni berkonsentrasi dan duduk hening akan mempercepat transformasi ini. Hati nurani anak-anak mulai membimbing mereka untuk bertindak yang benar, melakukan hanya yang baik bagi mereka sendiri dan bagi orang lain.Tipe belajar yang baru, dimulai. Pengetahuan dan pemahaman diperoleh secara intuitif tanpa harus menggunakan pikiran sadar. Bahkan dalam tahap ini pikiran sadar harus diam dan tenang sepenuhnya agar intuisi bisa bekerja (Jumsai, 2008: 11). Dalam hal ini diperlukan waktu yang tepat, untuk mengekspresikan ide-ide kreatif, dalam dunia pendidikan proseslah yang lebih penting daripada hasil.

Dengan mengaktifkan kreativitas yang dimiliki, orang akan menemukan sesuatu yang dahsyat, lebih bernilai, dan menjadi kekuatan diri sendiri dari segala sesuatu yang semula tampak sebagai keterbatasan, kelemahan, atau masalah (Latuconsina, 2014:25). Jadi manusia memerlukan waktu yang cukup untuk mematangkan dirinya, sehingga mampu menemukan sesuatu yang hebat (excellence).

Bagi mereka yang berkata "saya mampu", "saya bisa" sering sikap yang demikian itu dihadapkan kepada berbagai kesulitan yang pada gilirannya mereka menemui kegagalan di dalam upaya membangun hari esok lebih baik. Sebagai suatu ilustrasi, pengalaman suatu bangsa di dunia ini yang telah menemukan dan menguasai ilmu pengetahuan dan teknologi yang sangat canggih. Dengan suara lantang menyatakan bahwa "kami berhasil membangun rumah tahan gempa dengan ilmu pengetahuan dan teknologi yang tinggi. Kenyataannya ketika gempa melandanya, 
rumah yang dikatakan tahan gempa itu hancur total rata dengan tanah" ilustrasi ini menggambarkan bahwa kemajuan ilmu pengetahuan dan teknologi yang dipandang dan dipercaya mampu mengatasi berbagai masalah yang ada di hadapan kita dewasa ini, ternyata ilmu pengetahuan dan teknologi yang cangih tersebut belum mampu mengatasinya (menjawab) tantangan dan masalah. Jadi ketebatasan kemampuan manusia ini, bila tidak disadari oleh kita, akan membuat diri kita sakit, baik jasmani maupun ruhani. Pikiran kita menjadi kalut, tidak tenang dan tidak jernih di dalam memecahkan suatu persoalan (Gorda, 2005:34-35). Hal tersebut mengajarkan manusia janganlah takabur, dengan menganggap diri serba bisa dan serba mampu, maka ada sesuatu kekuatan yang menguji kemampuan manusia, disinilah diperlukan kebijaksanaan.

\subsection{Pengorbanan dan Kebijaksanaan}

Manusia dalam hidupnya harus banyak belajar dari alam, seperti matahari, tumbuhtumbuhan dan sebagainya. Contohnya sinar matahari tanpa diminta matahari selalu menyinari dunia ini tanpa henti-hentinya. Dalam hal ini kitab Niti Sataka 63, menguraikan mutiara-mutiara kebijaksanaan dalam melakukan pengorbanan sebagai berikut.

\section{Padmakāram dinakaro vicakam karoti candor vikāsayati kairavacakravālam nābhyarthito jaladharoapi jalam dadāti santah svayam parahiteșu krtābhiyogāh}

\section{Artinya :}

Tanpa diminta, sinar matahari memekarkan bunga lotus yang kuncup, bulan memekarkan bunga kamalini (sejenis bunga sedap malam), dan awan menjatuhkan hujan. Demikian pula orang baik menolong orang lain atas keinginan mereka sendiri (Somvir, 2005: 55).

Kebaikan sejati diumpamakan seperti : 1) sebagai emas murni walau dipanasi dan di tempa berkali-kali masih tetap cemerlang, 2) sebagai kayu cendana walau digosokgosokkan berkali-kali masih tetap mengeluarkan bau harum, 3) sebagai tebu walau dipotong berkali-kali masih tetap memiliki rasa manis (Subagiasta, 2006: 80). Jikalau kita bisa menirukan bagaimana mas, cendana tebu tersebut berkorban untuk orang lain, alangkah bahagianya dunia ini. Maka pengorbanan menjadi sangat penting dalam hidup ini untuk menempa diri kita menuju transformasi 'perubahan menyeluruh dalam diri'.

Bersikap bijaksana, jujur dengan memperlakukan keluarga dengan baik akan mendapatkan dukungan yang baik pula. Terkait dengan sikap seseorang dalam keluarga dijelaskan dalam kitab Niti Sataka, 18 seperti berikut.

Dāksinyam svajane dayā parijane sāthyam sadā durjane

pritih sādhujane nayo nrpajane vidvajjanesvarjavam

sauryam satrujane ksamā gurujane nārijaneadhrstatā

ye caivam purusāh kalāsu

kusalāstesveva lokasthitih.

Artinya:

Memperlakukan keluarga dengan baik, mengasihi orang lain, bersikap tegas terhadap penjahat, menghormati orang baik, bersikap bijaksana dengan para pemimpin, bersikap jujur, berani menghadapi musuh, pemaaf terhadap para guru, menghormati wanita, atas dasar sifat-sifat itulah kehidupan berjalan (Somvir, 2005: 16).

Orang yang penuh dengan kebijasanaan, tidak akan pernah mengenal rasa takut, baik dalam kena musibah dirundung malang dan yang lainnya. Dalam hal ini kitab Niti Sataka, 79 menguraikan sikap seorang bijaksana dalam menghadapi kehidupan yang tidak pernah takut terhadap musibah seperti berikut.

Chinnoapi rohati

tarūh

\section{kșinoapyupaciyate punascadrah}


iti vimrsantah santah santapyante na viplutāh loke.

\begin{abstract}
Artinya:
Meskipun pohon ditebang, tunasnya akan tumbuh kembali, bulan sabit pun dapat penuh kembali. Menyaksikan halhal tersebut, orang-orang bijaksana tidak pernah resah bila musibah datang (Somvir, 2005: 68).
\end{abstract}

Bila manusia dirundung kemalangan, bagi orang yang penuh dengan kebijaksaana mereka akan tetap merasa bersyukur, tidak resah, dan tidak mengenal takut. Disadari bahwa bekal manusia lahir di dunia ini adalah suka, duka, lara (sengsara), dan pati (mati). Pada akhirnya kematian adalah sebuah kepastian. Menyadari semuanya itu, manusia hendaknya memiliki kerendahan hati. Kerendahan hati adalah sebuah perhiasan yang sangat berharga dalam hidup ini.

\subsection{Kerendahan Hati dan Bersikap Tegas}

Manusia yang memilki budi pekerti yang luhur senatiasa memiliki sifat rendah hati. Ketika pengetahuan ada pada diri orang yang memiliki kerendahan hati, orang tersebut bagaikan setangkai padi, semakin tunduk semakin berisi. Dalam kitab Niti Sataka, 61 kerendahan hati yang bagaikan pohon yang penuh berisi buah semakin merunduk dijelaskan sebagai berikut.

Bhavanti namrāstaravah phalodgamairnavāmbubhirbhūmivilam bino ghanāh anuddhtāh satpuruṣāh samrddibhibhih svabhāva evaișa paropakāriņām

Artinya :

Pohon yang penuh buah semakin merunduk, awan yang penuh air semakin merendah ke bumi, demikian juga halnya dengan orang-orang baik yang mendapatkan kekayaan menjadi semakin rendah hati. Sifat dasar orang baik adalah rendah hati (Somvir, 2005: 53-54).
Pergaulan dengan orang bijaksana sangat menentukan orang tersebut memiliki sifat kerendahan hati. Dalam hubungannya dengan ini adalah penting menjalin satsangga (bergaul dengan orang-orang baik dan suci). Seperti sebuah ungkapan yang menyatakan "katakan kepadaku siapa temanmu, maka aku akan tahu siapa dirimu". Seseorang diketahui peringai dan tabiatnya dari teman bergaulnya. Adapun kerendahan hati pengaruh dari pergaulan dengan orang bijak, dijelaskan dalam kitab Niti Sataka, 7 adalah sebagai berikut.

Yada kincijjñyoaham dvipa iva madāndhah samabhavam

tadā sarvajno asmityabhavadavaliptam mama manah

yadā kiñcitkiñcid budhajana sakāśādavagatam

tadā mūrkhoasmīti jvar iva mado me vyapagatah.

\section{Artinya :}

Ketika menguasai sedikit pengetahuan, aku bagaikan seekor gajah yang mengamuk, penuh dengan keangkuhan dan merasa paling tahu segalanya, tetapi ketika mulai bergaul dengan orangorang bijaksana, maka kesombonganku perlahan-lahan mereda bagikan demam, dan akhirnya menyadari bahwa aku adalah orang bodoh (Somvir, 2005: 6).

Dengan menguasai pengetahuan hidup bisa tampak lebih indah, tentunya berdasarkan atas kebenaran, dalam ajaran agama Hindu dikenal dengan Sathyam, yang menuju pada hakekat kesucian. Menurut Dharsono keindahan pada dasarnya adalah sejumlah kualita pokok tertentu yang terdapat pada sesuatu hal. Kualita yang paling sering disebut adalah kesatuan (unity), keselarasan (harmony), kesetangkupan (symmetry), keseimbangan (balance), dan perlawanan (contrast) (Dharsono, 2007:2). Dalam kesatuan akan terdapat keselarasan dan keseimbangan pikiran, sehingga mampu mengontrol ucapan serta jalannya perbuatan yang berdasarkan kebenaran. 
Selanjutnya bersikap tegas serta sifatsifat tidak pernah menyerah dijelaskan dalam kitab Niti Sataka 21:

Kșutkșāmoapi jarākahsoapi
úithilaprāyoapi kaștāmdasā
māpannoapi vipannadidhitirapi
prāneșu nasyatsvapi
mattebhendra vibhinnakumbha
pisitagrāsaika baddhaspåhah
kim jimam trnamatti
mānamahatāmagresarah kesari.

Artinya :

Meskipun sedang kelaparan kurus karena ketuaan, kehabisan tenaga, menderita tidak berdaya bahkan diambang kematian, tetapi ingin memakan kepala seekor gajah yang sedang mengamuk. Apakah seekor singa yang menjadi raja hutan bisa puas dengan memakan rumput kering ? (Somvir, 2005: 20).

Dalam sloka di atas dimaksud manusia yang berjiwa besar tidak perlu mudah menyerah, dan selalu berjuang untuk mencapai tujuannya. Meskipun nyawanya terancam, mereka tidak pernah meninggalkan sifat yang baik dalam kehidupan mereka. Bagaikan seekor singa, meskipun sedang kelaparan, akan tetapi ia tidak akan puas hanya dengan makan rumput kering dan tetap mengejar mangsa yang diinginkannya.

Semua manusia menyadari bahwa sebenarnya semua impian manusia berujung pada satu hal yang benar-benar dasar yang diinginkan setiap orang, yaitu kedamaian pikiran. Kedamaian pikiran inilah yang dicari manusia. Dengan kedamaian pikiran inilah kualitas hidup dapat diraih (Vashdev, 2009: 104). Pertama yang diusahakan adalah melatih dan menemukan kedamaian pikiran. Manusia yang mampu mengolah alam pikirannya atau yang disebut dengan buddhi (intelek) adalah manusia yang paling baik di antara manusia, sebagaimana yang dijelaskan dalam kitab Manawa Dharma Çastra Bab I, sloka 96 adalah:
Bhutanam paninah çrethah,

Prainam buddhijiwinah,

Buddhimatsu narah çretha

Naresu brahmanah smrtah.

\section{Artinya:}

Di antara semua makhluk ciptaan itu manusia yang berakal (buddhi) yang paling utama, di antara manusia yang berakal brahmana yang paling baik.

Manusia dengan segala kwalitas yang dimilikinya, motorik atau alat penggeraknya adalah pikiran. Dari pikiran semuanya berasal, maka pikiran disebut sebagai rajanya indrya (Rajendrya). Lebih tinggi dari pikiran adalah buddhi (bagian yang lebih halus dari pikiran). Substansinya adalah pikiran diatur oleh buddhi dan buddhi dikendalikan oleh atma (jiwa), Jika manusia selaras dengan akal buddhinya yang diterangi oleh sinar atma maka terang pulalah jalan hidupnya. Jadi manusia yang berbudi adalah yang paling utama.

Sehubungan dengan hal tersebut, dalam kitab Sarasamuscaya, 473 disebutkan mengenai penyebab dari semua sebab adalah pikiran semata, sebagai berikut.

Manah kêta nimittaning sukhaduhkhan katêmu, nah yang padahi sajining rājya, manggala sang prabhu, sāmanya sahaninkang wwang ring antahpura rumêngö ya, hana pwa kumwa wiwekanya, tan grāhī, karêngö mara ya dengku, hilang pāpangku denika, ya ika sukha denika.

Artinya:

Pikiran menyebabkan dijumpainya suka dan duka. Gong (gamelan) perlengkapan kerajaan, tanda kemuliaan bagi raja, orang kebanyakan, pun semua wanita yang ada dalam puri itu mendengarkan bunyi gamelan itu. Ada yang berpendapat demikian. Tidak menarik bunyi gamelan itu. Sebaliknya, ada yang mengatakan, baru saja terdengar olehku, maka lenyaplah kesedihan hatiku olehnya, itulah yang 
menyebabkan kegembiraan hatiku (Kadjeng, 2010: 370).

\subsection{Independensi dan Wiweka dalam Menghadapi Modernisasi}

Hidup merupakan sebuah komunitas satu keluarga besar seperti yang diungkapkan Rama (2011: 160) pikiran yang luas, rasa kesetaraan, dan realisasi bahwa seluruh hidup ini adalah satu keluarga besar merupakan hasil dan akibat dari proses berpikir independen. Proses berpikir independen berarti kebebasan dari semua prasangka, keyakinan-keyakinan yang dangkal, dan praktik-praktik takhayul. Jika dibangkitkan dan dipulihkan secara tepat, spritualitas dapat menyelamatkan seluruh dunia dari hantaman materialisme yang destruktif. Manusia harus menyusun pikirannya untuk membangun kembali nilai-nilai peradaban yang lebih tinggi dan untuk mulai mempraktikkan filosofi ini yang sangat esensial bagi pertumbuhan kehidupan di sini dan bagi kehidupan selanjutnya.

Sementara itu di Bali tradisi gugon tuwon yang dianggap sebagai akar dari aktivitas religius juga mengalami pembantahan dari kaum intelektual muda Bali yang telah memperoleh pendidikan modern. Tradisi yang sarat dengan muatan lokal terhadap aktivitas keagaman yang telah terkonstruksi, yaitu praktik keagamaan lebih bercirikan sebuah warisan yang harus dilaksanakan seperti apa yang telah dipraktikkan pendahulunya (Triguna, 2011: 53).

Pendidikan modern

lebih mengedepankan pada sendi modernisasi, apa yang diinginkan harus segera dapat diwujudkan, dengan kata lain bahwa segala daya upaya untuk bisa mencapai tujuan bisa dengan berbagai macam cara. Hal itu Tampaknya bertentangan dengan nilai-nilai dan norma-norma yang diwarisi oleh para tetua atau sesepuh, dalam hal ini mengesampingkan tradisi yang ada sebelumnya. Selanjutnya dalam Sarasamuscaya 17 tentang segala pekerjaan bagi semua orang selama menyenangkan hatinya, disebutkan sebagai berikut.
Salwiraning wwang kaniștamadhyamottama tuwi, yāwat gawe hayu kajênêk ni hatinya, niyata siddhaning sasinādhyāna.

Artinya:

Semua orang, baik golongan rendah, menengah, maupun tinggi, selama kerja baik menjadi kesenangan hatinya, niscaya tercapailah segala yang diusahakan memperolehnya (Kadjeng, 2010: 19).

Dalam era milenial sekarang ini manusia lebih berorientasi pada kekayan duniawi semata (money oriented). Justru manusia berlomba-lomba untuk menumpuk kekayaan dan memenuhi segala keinginan yang tiada batas. Hal inilah yang dapat menjadi kebiasaan buruk yang membudaya dengan mempengaruhi pemikiran-pemikiran manusia lainnya. Budaya korupsi sudah sedemikian menggurita dan lama-kelamaan dianggap sebagai sesuatu hal yang wajar. Moralitas pun pada akhirnya mengalami degradasi nilai. Jika dikembalikan pada kebenaran nilai yang dituangkan oleh para penyair, khususnya dalam kitab Niti Sataka justru berbanding terbalik dengan pendidikan modern yang dikembangkan saat ini. Apabila dicermati, busana yang terindah secara hakiki bukanlah kekayaan materi, sebagaimana sloka 53 menguraikan sebagai berikut:

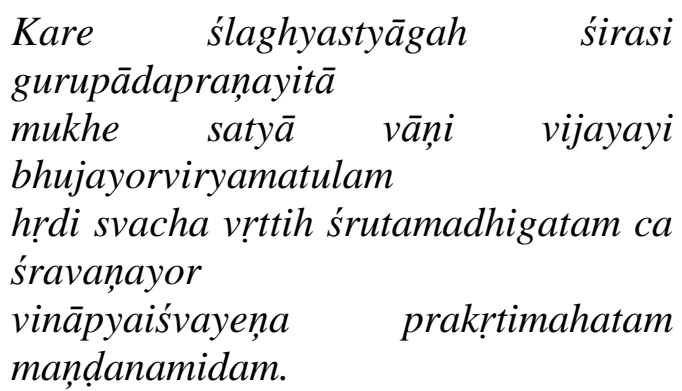

Artinya :

Tangan yang indah adalah tangan yang selalu menyumbang kepada orang lain, kepala yang agung adalah yang selalu menunduk di depan guru, keindahan bibir adalah yang selalu berkata benar, ketegangan bahu adalah yang memiliki kekuatan untuk menang, hati yang baik 
adalah yang memiliki belas kasihan, telinga yang indah adalah mendengarkan Weda, bagi orang-orang baik keindahan-keindahan tersebut merupakan busana yang terbaik, bukan kekayaan (Somvir, 2005: 46).

Tangan yang diberikan Tuhan alangkah indahnya jika dipakai untuk selalu melayani, menolong sesama manusia yang memerlukan, demikian juga bibir sangat indah apabila selalu mengucapkan kebenaran, hati yang baik selalu memiliki belas kasihan. Dalam ajaran Hindu perbuatan atau tingkah laku yang disucikan (suddha) dan juga indah (sundaram) yang berdasarakan kebenaran (satyam), penuh dengan kesucian (sivam), yang dikenal dengan konsep satyam, sivam, sundaram (kebenaran, kesucian, keindahan). Sesugguhnya pendidikan yang baik dan benar yang diperlukan adalah mensinkronkan antara kepala (head) tangan (hands) dan hati (heart). Apa yang dipikirkan, itulah yang diucapkan, dan apa yang diucapkan itulah yang harus dilakukan, sederhana dalam konsepnya namun untuk melakukan hal tersebut diperlukan sebuah komitmen. Dalam ajaran Hindu di Bali dikenal dengan Tri Kaya Parisuddha (tiga perbuatan yang selalu disucikan).

Bukanlah hanya orang pintar semata dalam pendidikan, tetapi diperlukan memiliki kebijaksanaan (wise). Kebijasanaan dalam hal ini adalah selalu berpikir sebelum berbuat. Hendaknya ditimang-timang dulu apakah hal itu baik atau buruk sebelum dilakukan, sebagaimana diuraikan dalam sloka 95:

\section{Guņavadaguñavadvā \\ kurvatā \\ kāryamādau \\ pariņatiravadhāryā yatnatah paṇditena atirabhasakrtānām karman̄āmāvipatter bhavati hrdayadāhi śalyatulyo vipākah.}

Artinya :

Orang yang bijaksana, sebelum memulai pekerjaan apapun, ia memerhitungkan baik dan buruknya dengan teliti karena pekerjaan yang dilakukan dengan terburu-buru akan membawa pahala yang pahit seumur hidup, bagaikan duri dalam hati (Somvir, 2005: 82).

Pekerjaan yang dilakukan dengan cara terburu-buru, hasilnya jelas kurang baik untuk kehidupan ini. Jadi diperlukan penyaring (filter) dengan mengedepankan wiweka (memilah-milah) man yang baik dan yang buruk, sehingga tidak terjadi penyesalan dikemudian hari. Disinilah kebijaksanaan diperlukan, tidak saja kepintaran semata, orang bijaksana sudah tentu pasti pintar, akan tetapi orang pintar belum tentu bijaksana.

\section{SIMPULAN}

Berdasarkan pembahasan di atas, dapat disimpulkan bahwa nilai-nilai pendidikan yang terkandung dalam kitab Niti Sataka merupakan ajaran yang penuh dengan etika dan moralitas dalam kehidupan untuk diimplementasikan dalam kehidupan nyata dalam dunia pendidikan sehingga dapat disebarluaskan di masyarakat serta mampu mencetak genarasi Hindu yang punya dedikasi tinggi dan bertanggungjawab dalam bidangnya sesuai dengan keterampilan yang dimiliki. Dengan berpegang teguh pada kebenaran, hidup penuh kesucian lahir dan batin dengan selalu menjaga keselarasan antara pikiran, perkataan, dan perbuatan (Tri Kaya Parisudha) niscaya keindahan dalam hidup ini akan selalu bersinar terang.

\section{DAFTAR PUSTAKA}

Bhahtrihari, 2005. Niti sataka, 100 sloka tentang Etika dan Moralitas terjemahan Dr. Somvir; Pt. Empat Warna Komunikasi.

Darmayasa. 2014. Bhagawadgita (Nyanyian Tuhan). Denpasar: Yayasan Dharma Sthapanam.

Gautama, Wayan Budha. 2005. Dharma Pamacul Tuntunan Para Petani, Menurut Lontar. Surabaya: Paramita.

Gorda, I Gusti Ngurah. 2005. Membangun Kecerdasan Intelektual Melalui Jalan Spiritual : Menata Kesuksesan Berpikir Arif Bali: Asta Brata. 


$\begin{array}{lr}\text { Lembaga Manajemen } & \text { Spritual } \\ \text { Denpasar. } & \\ \text { Jumsai Na-Ayudhya.2008, } & \text { Model } \\ \text { Pembelajaran } & \text { Nilai-nilai } \\ \text { Kemanusiaan Terpadu (Human Values } \\ \text { Integrated Instructional Model) } \\ \text { Pendekatan yang efektif untuk } \\ \text { Mengembangkan Nilai-Nilai } \\ \text { Kemanusiaan atau Budi Pekerti pada } \\ \text { Peserta Didik. Jakarta: Yayasan } \\ \text { Pendidikan Sathya Sai Indonesia. }\end{array}$

Kadjeng, dkk. Sarasamuscaya. Denpasar : Dharma Nusantara.

Kartika, Dharsono Sony. 2007. Estetika. Bandung: Rekayasa Sains.

Latuconsina, Hudaya. 2014. Pendidikan Kreatif. Menuju Generasi Kreatif dan Kemajuan Ekonomi Kreatif di Indonesia. Jakarta: PT Gramedia Pustaka Utama.

Rama, Swami. 2005. Hidup Dengan Para Rși Himālaya. Surabaya: Paramita.

2011. Spiritualitas Transformasi ke Dalam dan ke Luar Diri. Surabaya: Paramita.

Sandhi, Gde, Pudja, Gede. 1979. Brahmanda Purana. Proyek Pengadaan Kitab Suci Hindu Departemen Agama R.I.

Subagiasta, I Ketut. 2006. Saiva Siddhānta di India dan di Bali. Surabaya : Paramita.

Suwantana, I Gede. 2013. Gandhi Giri Ajaran Mahatma di Bali. Klungkung: Asram Gandhi Puri Indra Udayana Institute of Vedanta.

Titib, I Made. 1994. Ketuhanan Dalam Weda. Denpasar: PT Pustaka Manikgeni.

Vashdev, Gobind. 2009. Happiness Inside. Jakarta: Hikmah (PT Mizan Publika).

Yuda Triguna, IB Gde. 2011. Mengapa Bali Unik. Jakarta: Pustaka Jurnal Keluarga. 